\title{
A REVIEW ON THE ANTIPARASITIC DRUG IVERMECTIN FOR VARIOUS VIRAL INFECTIONS AND POSSIBILITIES OF USING IT FOR NOVEL SEVERE ACUTE RESPIRATORY SYNDROME CORONAVIRUS 2: NEW HOPE TO TREAT CORONAVIRUS DISEASE-2019
}

\author{
TALHA JABEEN ${ }^{1 *}$, MOHD ABDUL KHADER ${ }^{1}$, SHAYESTHA JABEEN ${ }^{2}$ \\ ${ }^{1}$ Department of Pharmacy Practice, Bhaskar Pharmacy College, Jawaharlal Nehru Technological University, Hyderabad, Telangana, India. \\ ${ }^{2}$ Department of Pharmacy Practice, MRM College of Pharmacy, Jawaharlal Nehru Technological University, Bongloor, Telangana, India. \\ Email: talhajabeen9191@gmail.com
}

Received: 17 May 2020, Revised and Accepted: 20 June 2020

\begin{abstract}
The novel coronavirus infection has spread all over the world. With no specific drug or vaccine, the process of "drug repurposing" becomes a feasible solution. As severe acute respiratory syndrome coronavirus 2 (SARS-CoV-2) has $80 \%$ sequence similarity with the SARS-CoV, the nuclear import inhibitor "Ivermectin" (IVM) has recently been studied as a possible treatment option for coronavirus disease-2019 (COVID-19). The article aims to provide a review on structure and immunogenicity of SARS-CoV-2, indications of IVM for viral diseases, its possible mechanism on COVID-19 with a brief discussion on IVM structure, pharmacokinetics, adverse drug reactions, drug interactions, and contraindications. Further, we made possible comparisons of IVM with solidarity trial drugs and analyzed its major advantages, limitations and gave necessary recommendations for its use in future in vivo studies in the treatment of COVID-19.
\end{abstract}

Keywords: Severe acute respiratory syndrome coronavirus 2, Coronavirus disease-2019, Ivermectin, Drug repurposing, Solidarity trial.

(c) 2020 The Authors. Published by Innovare Academic Sciences Pvt Ltd. This is an open access article under the CC BY license (http://creativecommons. org/licenses/by/4. 0/) DOI: http://dx.doi.org/10.22159/ajpcr.2020.v13i8.38357

\section{INTRODUCTION}

In December 2019, multiple cases of pneumonia with unknown cause were detected in Wuhan, Hubei Province of China. Soon, the health authorities have found links to these cases with South China seafood market. With the doubt of the origin of a similar outbreak in China in the year 2002 (severe acute respiratory syndrome coronavirus 2 [SARS-CoV]) and 2012 (Middle East Respiratory Syndrome, [MERS-CoV]) and a new zoonosis transmission, the investigation was undertaken that have since identified a novel coronavirus, SARS-COV-2 (Formerly 2019-nCoV) [1]. This novel SARS-CoV-2 has taken the world by storm through the current outbreak of coronavirus disease-2019 (COVID-19) and continues to spread in every continent except Antarctica. As of May 17, 2020, there have been 4,736,104 confirmed cases and 313,498 deaths with World Health Organization (WHO) calling the outbreak "global health emergency" in January 2020 and have now declared COVID-19 a "global pandemic" because of the unusually fast rate in which the virus is spreading. China as of now in May has controlled its peak and Europe has now emerged as the new epicenter of COVID-19 pandemic [2,3].

As it is a newly emerged virus, researchers have taken quick actions to isolate the viruses and perform gene sequencing, making identifying treatments possible. As an urgent need for pharmacological therapies is on exponential demand due to high infection and mortality rates, developing now, a new drug or vaccine seems to be a difficult and timeconsuming task. With time requiring to explore their biotherapeutics and to achieve global immunization, millions of people already could have infected or dead. Therefore, the idea of "Drug repositioning" (also called repurposing), i.e., the investigation of existing approved drugs for new therapeutic purposes, seems to be logical to provide treatment as fast as possible to the millions of COVID-19 survivors most safely and cost-effectively [4,5]. Ivermectin (IVM), one such drug which is originally used to treat parasitic infections, has recently been found to inhibit the replication of novel SARS-CoV-2 within $48 \mathrm{~h}$ in laboratory settings [6]. The very recent observational registry-based study from 169 hospitals across different countries revealed that IVM treated group of COVID-19 critically ill patients requiring mechanical ventilation has lower mortality and healthcare resource used [7]. IVM is an Food and Drug Administration (FDA)-approved anti-parasitic drug that has also been shown to be effective in vitro against a broad range of viruses, including human immunodeficiency virus (HIV), dengue, and influenza $[8,9]$.

This article reviews the structure and immunogenicity of SARS-CoV-2, uses of IVM for various viral diseases, its possible role for SARS-CoV-2, and briefly explaining its structure, pharmacokinetics (PK's), adverse drug reactions (ADR's), drug interactions (DI's), contraindications (CI's), and finally its comparison over safety, efficacy, and ease of administration to the drugs in the solidarity trial.

\section{SARS-COV-2}

SARS-CoV-2 belongs to beta-coronavirus lineage $\beta$, sarbecovirus, where SARS-CoV and MERS-CoV are included. By forming a new clade different from SARS-CoV and MERS-CoV, it became the seventh member of the coronavirus family to infect humans. This novel virus was initially identified through the next gene sequencing and suggested to have a possible zoonotic origin [10].

The whole-genome sequencing of the novel coronavirus reveals that it shares a $40 \%$ sequence similarity with MERS- $\mathrm{CoV}$ and $80 \%$ sequence similarity with SARS-CoV, indicating that SARS- CoV-2 is much more comparable with SARS-CoV [11].

The novel coronavirus is an envelope, single, and positive-stranded RNA virus. The virus particles are round or oval, with an average diameter of about $60-140 \mathrm{~nm}$.

The transmission electron microscopy imaging of SARS CoV-2 from Indian researchers indicated their relatively shorter size and a possible multi-aggregate of the peplomer [12]. A peplomer is a glycoprotein spike on a viral capsid or viral envelope binding to certain receptors on the host cells and is essential for both host specificity and viral 
infectivity. With immunogenicity much closer to SARS-CoV, it has been found that SARS-CoV-2 uses the SARS-CoV receptors angiotensinconverting enzyme 2 for entry and serine protease TMPRSS2 for S protein priming [13]. Further, SARS-CoV proteins have revealed a potential role for IMP $\alpha / \beta 1$ during infection in the single-dependent nucleocytoplasmic shutting of the SARS-CoV nucleocapsid protein that may impact host cell division [14].

SARS-CoV-2 has the typical beta-coronavirus organization: 5' untranslated region (UTR), replication enzyme coding region, S gene, E gene, M gene, N gene, 3' UTR, and several unidentified non-structural open reading frames (ORFs). It was revealed before that the accessory ORFs of SARS-CoV are unique to each different strain of $\mathrm{CoV}$ and are predicted to encode functions important in pathogenesis. Among the SARS-CoV accessory ORFs-ORF3a, ORF6, ORF7a, and ORF7b are not essential for in vitro or in vivo replication or release of infectious viruses, but each one of them is reported to be incorporated into the virion [15].

\section{IVM}

The labeled "Wonder drugs," avermectins were discovered by Omura and Campbell from the bacterium Streptomyces avermitilis. After purifying avermectins from a culture obtained from Omura by Campbell and led efforts leading to the discovery of IVM in 1975, a derivative of greater potency and lower toxicity. IVM, the first avermectin drug, was introduced as a veterinary drug by Merck and Co. in 1981, and new formulations were released every year. At that time, the human use of IVM was not much established. It was in 1987, IVM was first registered as human drug under the brand name Mectizan ${ }^{\circledR}$ after its efficacy against filarial nematodes were shown.

In 1988, IVM was first used to treat onchocerciasis in humans. As the years passed, its efficacy for an expanding number of other parasitic diseases was established. Interest has mainly grown on IVM as it showed greater potency and lower toxicity for treating parasitic infections. It is worth noting that half of the 2015 Noble Prize in Physiology and Medicine was awarded jointly to Campbell and Omura for their discovery of IVM. Since its discovery, the anti-parasitic uses of IVM have increased and its promising role in non-parasitic infections continues to accumulate. The drug is approved by FDA and is on the WHO's list of essential medicine.

Today IVM is one of the most used and best known antiparasitic drugs in human and veterinary medicine. IVM currently uses for the treatment of lymphatic filariasis, onchocerciasis, strongyloidiasis, trichinellosis, ectoparasite infestations, pediculosis, scabies, myiasis, and malaria. The antiparasitic activity of IVM is through the activation of glutamategated chloride channels, $\gamma$-aminobutyric acid (GABA) transmission in worms, and thereby resulting in their paralysis and death $[14,16]$

\section{IVM FOR VIRAL DISEASES}

IVM has shown a promising treatment option for certain viral pathogens. We conducted a literature search of Google Scholar, PubMed, and Scopus databases regardless of the publication dates of the articles. All search protocols were in accordance with Preferred Reporting Items for Systemic Reviews and Meta-Analysis (PRISMA) guidelines for systemic reviews. The keywords such as "IVM" and "VIRAL INFECTIONS" were used. The titles of the top 200 articles from 1960 to 2020 were then read. After screening for their appropriateness and removing duplicates, a total of 11 articles met the inclusion criteria revealing the potential anti-viral efficacy of IVM for 12 viral pathogens which are summarized in Table 1.

From all these studies mentioned in Table 1, it can be concluded that IVM exerts its antiviral activity mainly through inhibition of nuclear import activity. Most of the mentioned studies concluded that IVM possesses a dose-dependent antiviral activity. However, at higher doses, cytotoxicity can also occur [22]. These studies were primarily performed in in vitro settings.

\section{IVM AND SARS-COV-2}

As the immunogenicity of SARS-CoV-2 is much closer to that of SARS$\mathrm{CoV}$, studies on SARS- CoV protein have revealed a potential role for $\operatorname{IMP} \alpha / \beta$ during infection in signal-dependent nucleocytoplasmic shuttings of the SARS-CoV nucleocapsid proteins that may disrupt the host cell division [28]. In another study by Mathew Frieman, it was found that accessory SARS ORF6 antagonizes STAT1 function by sequestering nuclear import factors on the rough endoplasmicreticulum/Golgi membrane [15].

As IVM has been an effective anti-viral agent through nuclear transport inhibitory activity (observed from the Table 1), it can inhibit importin $\alpha / \beta$ mediated transport of SARS-CoV- 2 viral proteins into the nucleus resulting in the inhibition of SARS-CoV-2 RNA replication process. The mechanism of action of IVM against SARS-CoV-2 is shown in Fig. 1.

The recent study by Caly et al. [6] from Australia has evaluated the above promising mechanisms of IVM for SARS-CoV-2. The study reveals that IVM at a dose of $5 \mu \mathrm{M}$ inhibits the replication of SARS-CoV-2 in vitro with an $\mathrm{IC}_{50}$ of $2.2-2.8 \mu \mathrm{M}$, which is similar to the efficacy of IVM in dengue virus ( $\mathrm{IC}_{50}: 2.2 \mu \mathrm{M}$ for DENVI). Further, a single addition of IVM 2 -h post-infection with SARS-CoV- 2 was able to effect $\approx 5000$ fold reduction in viral RNA at $48 \mathrm{~h}$. At $24^{\text {th }} \mathrm{h}$, there was a $93 \%$ reduction in viral RNA and a $99.98 \%$ reduction at $48^{\text {th }} \mathrm{h}$. In an observational registrybased study [7] from 169 hospitals with 1970 COVID-19 patient's with lung injury requiring mechanical ventilation across Asia, Europe, Africa, North, and South America, the IVM, $150 \mathrm{mcg} / \mathrm{kg}$ treatment group $(n=52)$ has lesser mortality rate, length of stay in intensive care unit and hospital compared to that of $\mathrm{n}=1918$ conventionally treated patients (mortality rate $=7.7 \%$ vs. $18.6 \%$; hospital length of stay $=10.9 \pm 6.1$ days vs. $15.7 \pm 8.1$ days, and intensive care unit length of stay $=6.0 \pm 3.9$ days vs. $8.2 \pm 6.2$ days for IVM, and conventional treatment group resp, all at $\mathrm{p}<0.001$ resp). This study was first of its kind for evaluating the significance of IVM in the treatment of COVID-19 in in vivo.

These results make IVM a possible candidate for COVID-19 drug repurposing research.

\section{STRUCTURE, PK'S, ADR'S, DI'S, AND CI'S TO IVM}

\section{Structure}

The avermectins are a class of macrocyclic lactones with nematocidal, acaricidal, and insecticidal activities. IVM is a derivative of naturally occurring avermectin B1, composed of approximately $80 \%$ of 22,23-dihydroavermectin B1a ( molecular weight, $875.10 \mathrm{~g} / \mathrm{mol}$ ) and approximately $20 \%$ 22,23-dihydro-avermectin B1b ( molecular weight, $861.07 \mathrm{~g} / \mathrm{mol}$ ) [14].

The structural components of IVM are shown in Fig. 2. The structure is downloaded from (https://dailymed.nlm.nih.gov) [29].

\section{PK's}

The IVM has favorable PK characteristics. IVM can be given orally, topically, or through injection. However, only oral IVM is a licensed route of administration for human use. It has rapid oral absorption, and higher lipid solubility and is widely distributed in the body. It reaches peak plasma levels in 3.5-5 $\mathrm{h}$ after an std. oral dose in healthy humans and plasma half-life has been reported to be 12-66 h. Oral IVM is available in different forms, i.e., solution, tablet, and capsules with solutions having approximately twice systemic availability compared with solid forms (tablets and capsules). Its bioavailability gets increased post-high-fat meal intake due to its higher lipid solubility. For healthy adults, the volume of distribution is approximately 46.9 l. It has $93 \%$ protein binding and elimination half-life of $18 \mathrm{~h}$. It is metabolized in the liver microsomes by a cytochrome p450 enzyme system with at least ten metabolites, mostly hydroxylated and demethylated derivatives. Excretion mainly occurs in feces in about 12 days. Less than $1 \%$ of the drug is excreted in the urine. It does not readily cross the bloodbrain barrier due to the presence of p-glycoprotein, but crossing can be significant at higher doses [14]. 
Table 1: Indications of IVM for viral diseases

\begin{tabular}{|c|c|c|c|c|c|}
\hline Virus & Disease & Study design & IVM dose $(\mu \mathrm{m})$ & Mechanism of action of IVM & Reference \\
\hline Dengue virus (DENV1-4) & Dengue & In vitro & $0.4-45$ & $\begin{array}{l}\text { By inhibiting importin } \alpha / \beta \\
\text { mediated transport of viral proteins } \\
\text { into the nucleus }\end{array}$ & [17] \\
\hline Pseudorabies virus (PRV) & Pseudorabies & In vitro+In vivo & $2.5,5$ & $\begin{array}{l}\text { By inhibiting nuclear import of PRV } \\
\text { UL42 }\end{array}$ & [18] \\
\hline $\begin{array}{l}\text { Porcine reproductive and } \\
\text { respiratory syndrome } \\
\text { virus (PRRS) }\end{array}$ & $\begin{array}{l}\text { Porcine reproductive } \\
\text { and respiratory } \\
\text { syndrome }\end{array}$ & In vitro & $1-15$ & $\begin{array}{l}\text { Inhibits PRRSV infection in PAM- } \\
\text { PCD } 163 \text { cells }\end{array}$ & [19] \\
\hline $\begin{array}{l}\text { Chikungunya virus } \\
\text { (CHIKV) }\end{array}$ & Chikungunya & In vitro & $0.1-10$ & $\begin{array}{l}\text { Inhibiting intracellular viral RNA } \\
\text { synthesis }\end{array}$ & {$[20]$} \\
\hline $\begin{array}{l}\text { Human immunodeficiency } \\
\text { virus-1 (HIV-1) }\end{array}$ & $\begin{array}{l}\text { Acquired } \\
\text { immunodeficiency } \\
\text { syndrome }\end{array}$ & In vitro & 25,50 & $\begin{array}{l}\text { By inhibiting importin } \alpha / \beta \\
\text { mediated transport of viral proteins } \\
\text { into the nucleus }\end{array}$ & {$[21]$} \\
\hline $\begin{array}{l}\text { Newcastle disease virus } \\
\text { (NDV) }\end{array}$ & $\begin{array}{l}\text { Virulent Newcastle } \\
\text { disease }\end{array}$ & In vitro & $0.25,12.5,25,50$ & $\begin{array}{l}\text { By inhibiting importin } \alpha / \beta \\
\text { mediated transport of viral proteins } \\
\text { into the nucleus }\end{array}$ & {$[22]$} \\
\hline Zika virus (ZIKV) & Zika virus disease & In vitro & $0.1-100$ & $\begin{array}{l}\text { By inhibiting importin } \alpha / \beta \\
\text { mediated transport of viral proteins } \\
\text { into the nucleus }\end{array}$ & {$[23]$} \\
\hline Bovine herpes virus (BHV) & $\begin{array}{l}\text { Rhinotracheitis, } \\
\text { vaginitis, } \\
\text { balanoposthitis, } \\
\text { abortion, } \\
\text { conjunctivitis, enteritis }\end{array}$ & In vitro & $5,12.5,25$ & $\begin{array}{l}\text { By inhibiting nuclear import } \\
\text { of UL42 and reducing BOHV-1 } \\
\text { replication }\end{array}$ & {$[24]$} \\
\hline $\begin{array}{l}\text { Venezuelan Equine } \\
\text { encephalitis virus (VEEV) }\end{array}$ & $\begin{array}{l}\text { Venezuelan equine } \\
\text { encephalitis }\end{array}$ & In vitro & 1 & $\begin{array}{l}\text { By inhibiting importin } \alpha / \beta \\
\text { mediated transport of viral proteins } \\
\text { into the nucleus }\end{array}$ & {$[25]$} \\
\hline Yellow fever virus (YFV) & Yellow fever & In vitro & $\begin{array}{l}0.78,1.56,3.13 \\
6.25,12.5,25,50 \\
100\end{array}$ & By inhibiting N S3 helicase & {$[26]$} \\
\hline
\end{tabular}

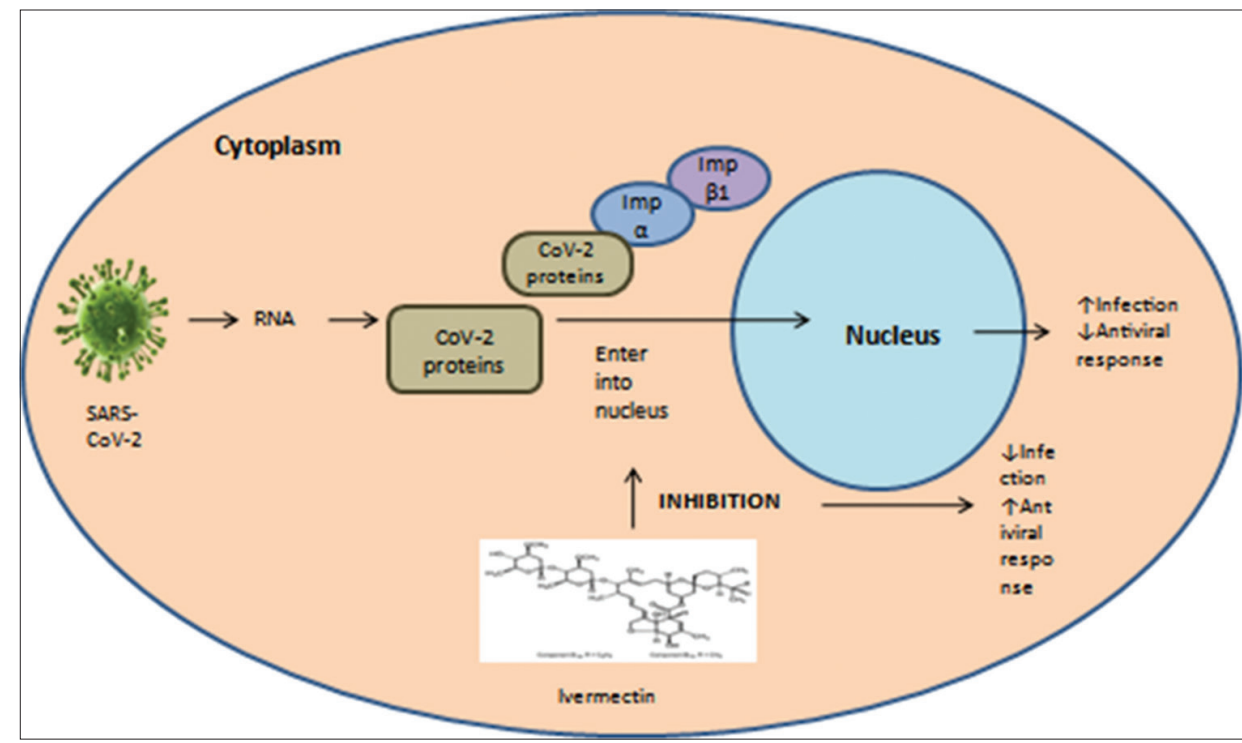

Fig. 1: Mechanism of action of Ivermectin against severe acute respiratory syndrome coronavirus 2

General dose and administration: IVM is administered as a single dose of $150 \mathrm{mg} / \mathrm{kg}$ given annually for its antifilarial activity.

$3 \mathrm{mg}$ PO (15-24 kg): Doses can be given according to body weight and incorporated as $6 \mathrm{mg}$ (35 kg), $9 \mathrm{mg}$ (50 kg), $12 \mathrm{mg}$ ( $65 \mathrm{~kg}$ ), and $15 \mathrm{mg}$, $150 \mathrm{mcg} / \mathrm{kg}$, and $200 \mathrm{mcg}$ per $\mathrm{kg}(\geq 80 \mathrm{~kg})$.
IVM should be taken on an empty stomach (1 $\mathrm{h}$ before a meal) or 2 -h post-meal.

\section{ADR's}

IVM is a generally well-tolerated drug with a good safety profile. The drug is used approximately 250 million people for parasitic diseases 


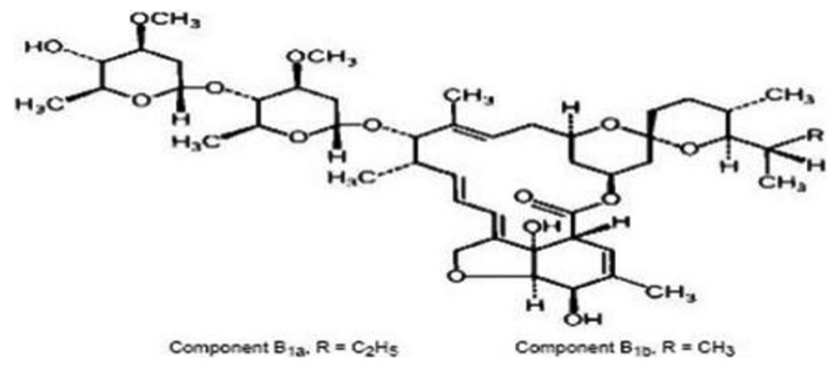

Fig. 2: Structural components of ivermectin

because of its greater potency and lower toxicity. The most common adverse effects reported include myalgia, rashes, node tenderness, swelling, itching, fever and chills, limb, joints, and facial swelling. The effects are usually mild to moderate and respond well with analgesics or anti-histamines. They almost always appear during the first 3 days following treatment and subside thereafter with a reduction in parasitic load. Further, these ADR's effects are mainly linked to an immune mechanism with parasitic involvement.

An uncommon severe potentially dangerous symptomatic postural hypotension occurred in 37 of approximately 14,000 patients treated in Ghana and was associated with fainting, sweating, tachycardia, and rarely confusion. Systemic corticosteroids instituted in such patients, but their requirement was not established [30].

Neurotoxicity has also been the main concern, but reviews of the cases with the extensive post-marketing experience show that several such events are likely to be rare, with controversial mechanisms mostly suggesting the role of concomitant infections such as Loa-Loa allowing IVM penetration into the central nervous system (CNS) due to Mdr-1 gene in humans.

In a large scale study from eight community trials with 50,929 patients given IVM and monitored for $72 \mathrm{~h}, 9 \%$ reported with ADRs, $2.4 \%$ with moderate reactions, and $0.24 \%$ with severe reactions, three cases of life-threatening dyspnea apart from postural hypotension were reported. The investigation suggested that IVM is sufficiently safe for large scale treatment and monitoring for at least $36 \mathrm{~h}$ by resident nurses is recommended [31]

No significant changes in electrocardiographic parameters were observed in IVM treated patients.

In a study by Plaque et al. with 200 pregnant women's treated with IVM, the risk of fetal damage was not greater than in control women's. The investigation recommends most of the pregnant women treated with IVM should continue its use [32].

The Mazzotti reaction can occur during the treatment of filariasis. However, the reaction is more common with Diethylcarbamazine and less likely with IVM, manifesting as complex of multiple infections and respond well with I.V. therapy of methylprednisolone.

Regarding blood-related disorders, hamatomatous swelling was reported in 2 out of 28 onchocerciasis patients treated with IVM $(50 \mu \mathrm{g} / \mathrm{kg})$ with increment in prothrombotic time above baseline by 1 week to 1 month after drug ingestion.

\section{Interactions}

Since IVM is metabolized by the CYP450 enzyme system, the inhibition and induction of the enzyme can influence the IVM metabolic activity. Doxycycline enhances IVM induced suppression of microfilariae virus and has beneficiary effects. Information about the influence of food in Pk's of IVM is scarce. Coadministration of alcohol with IVM is not recommended because IVM is associated with GABA receptors and the effect of alcohol in the CNS. The plasma concentration of IVM was significantly greater in patients who drank $750 \mathrm{ml}$ beer $(66.37,109$, and $97.2 \mathrm{ng} / \mathrm{ml}$ at 1,3 , and $4 \mathrm{~h}$ resp) versus those who drank $750 \mathrm{ml}$ water (44.0, 67.5, and $58.7 \mathrm{ng} / \mathrm{ml}$, resp, $\mathrm{p}<0.01$ at each time point).

IVM administration with orange juice or water resulted in a decreased area under the curve with orange juice $(15.7 \mathrm{ng} / \mathrm{ml})$ and $\mathrm{C}_{\text {max }}$ $(20.7 \mathrm{ng} / \mathrm{ml})$ compared to water $(33.8 \mathrm{ng} / \mathrm{ml}$, and $24.3 \mathrm{ng} / \mathrm{ml})$ possibly because fruit juice and constituents are potent inhibitors of certain drugs transporters [33].

\section{COMPARISON OF IVM WITH SOLIDARITY TRIAL BY THE WHO}

The WHO has initiated a solidarity trial of four most promising COVID-19 treatments, to find out whether any of these can treat infections from the novel coronavirus, causing dangerous respiratory disease.

The drugs that solidarity will test are:

1. Remdesivir

2. Chloroquine and hydroxychloroquine (HCQ).

3. Ritonavir and lopinavir

4. Ritonavir, lopinavir, and interferon $\beta$.

The efficacy of all the above drugs for novel SARS-CoV-2 has been proposed by the researchers extensively.

\section{Remdesivir}

Originally developed as a treatment option for Ebola virus disease and Marburg virus infection and did not make to come in the market yet and is not licensed nor approved by the FDA. The drug had shown promising results for the previous coronavirus SARS-CoV and MERS$\mathrm{CoV}$ and is currently hoping to provide treatment for SARS-CoV-2.

However, the data on its safety profile are lacking. As a typical antiviral drug, it has shown side effects such as nausea and vomiting. In the Ebola trial, researchers detected increased liver enzymes in their patients. Similar adverse effects of remdesivir in increasing liver enzymes are documented by $23 \%$ of COVID-19 patients [34]. Further, many ADR's of drugs are mainly documented during its post-marketing surveillance. As the drug is soon to come to patients because of the unmet patient needs from COVID-19, a longer time may be needed to establish its safety. Remdesivir can only be administered through intravenous injection, which makes difficulty for its production, requiring sterile drug product manufacturing and administration to COVID-19 patients as the presence of doctor or nurse to administer the medicine is must, regarding their safety and protection and in case if there is a shortage of healthcare workers. Further, it is an expensive drug. As IVM is in the market for four decades and is used annually by 250 million people, it has good oral bioavailability and affordable price, IVM, if it shows good efficacy for SARS CoV-2 in large trials, could be much a patient-friendly treatment option.

\section{Chloroquine and HCQ}

Chloroquine and HCQ have taken the pharma industry to storm with a rush in its requirement since the studies published its efficacy for SARS-CoV-2. The drug primarily used for Malaria was discovered back in 1934. Chloroquine has a variety of side effects, and, in some cases, can cause more harm than good [35]. Both chloroquine and HCQ can cause cardiac electrocardiogram QT-prolongation and subsequent arrhythmias, including torsade de points. The drugs have several drug interactions, and there is also not enough data to determine whether chloroquine is safe to be given to patients aged 65 and older. As the old age is more at risk for illness with SARS-CoV-2 and deaths, chloroquine, if given to them, should additionally be a monitor for its toxicity on kidney function. Since IVM has very few adverse effects, it could provide better safety over chloroquine and HCQ under large study trials.

\section{Ritonavir/lopinavir}

Is a fixed-dose combination medicine used for the treatment and prevention of HIV/AIDS. The combination is an effective treatment 
option for the COVID-19 with trials going on. As an antiviral drug, they have an adverse effect of causing nausea and vomiting, diarrhea has been observed in $27 \%$ of patients in the clinical trials. Elevation in liver enzymes is commonly observed during ritonavir/lopinavir treatment. It has varying degrees of interactions with other medications that are also CYP3A or P-glycoprotein substrates. FDA has issued safety labels in patients with heart patients [36]. Further, the drug is high in cost. Therefore, IVM with lesser adverse effects and cost could be a better option if it gets satisfied with clinical trial results.

\section{Ritonavir/lopinavir+interferon- $\beta$}

Solidarity is also having an arm that combines the two antivirals with interferon- $\beta$, molecules used for communication between cells to trigger the protective defense of the immune system that helps to eradicate the pathogens. Interferons are mostly administered by intramuscular injections. Interferon therapy in addition to side effects of flu-like symptoms, ill feel, analgesia, and convulsions can cause immunosuppression [37]. The decreasing efficacy of the immune system could worsen the COVID-19 patient's condition instead of helping them. The cost of interferons is also much higher. Therefore, IVM with less adverse events and cost affordability could be a better option for patients if larger trials get success.

\section{LIMITATIONS AND RECOMMENDATIONS FOR IVM IN THE TREATMENT OF COVID-19}

The major limitation of all these previous studies (mentioned in Table 1) is the efficacy of IVM as an antiviral agent has been performed in-vitro only with the exception of pseudorabies virus done both in vivo (mice) and in vitro. Recently published report of IVM efficacy against novel SARS-CoV-2 by Australian researchers has also been performed in in vitro laboratory settings. We found only a single study indicating IVM use for COVID-19 patient's in humans. Further, we also think that the dosage adjustment of IVM when treating COVID-19 is particularly important as cytotoxicity was observed at higher doses. Schmith et al. [38] stated that the drug concentration required to kill SARS-CoV-2 $\left(\mathrm{IC}_{50}, 2 \mathrm{Mm}\right)$ as reported by Caly et al., and was $>35 \times$ higher than maximum plasma concentration $\left(\mathrm{C}_{\max }\right)$ after oral administration of an approved dose of IVM when given fasting, though, the usual dose of IVM $150 \mathrm{mcg} / \mathrm{kg}$ used by Patel et al. and was found satisfactory in treating COVID-19 patients. Therefore, the possible safety and efficacy of IVM use for viral infections in humans need much validation. Large scale studies on animals and humans are needed to determine whether IVM might be safe and effective to prevent or treat COVID-19.

We also suggest that people should be made aware to not self-medicate by taking IVM intended for animals, as it was witnessed with an elderly couple taking chloroquine phosphate, an additive use to clean fish tanks as a prophylactic measure for COVID-19 resulted in the death of a man and his wife needing critical care. There could be a rush in the market for IVM by people, so pharmacists must not dispense IVM without prescription by licensed health-care providers. The authorities should be watchful for the selling of IVM in the market in comparison to the previous years and make sure that the drug should be available for the ones who need it.

\section{CLINICAL TRIALS DESIGNED TO STUDY THE EFFECTIVENESS OF IVM IN TREATING COVID-19}

A total of seven clinical trials have been registered under Clinical Trials.gov aim to evaluate the efficacy of IVM in treating COVID-19 (Table 2) [39-45].

Table 2: Different clinical trials registered under clinical trials.gov to evaluate the efficacy of IVM against SARS-CoV-2

\begin{tabular}{|c|c|c|c|c|c|c|}
\hline S. no. & Study title & Intervention/treatment & Phase & $\begin{array}{l}\text { Estimated } \\
\text { enrollment }\end{array}$ & $\begin{array}{l}\text { Actual/ } \\
\text { Estimated } \\
\text { study start date }\end{array}$ & $\begin{array}{l}\text { Actual/Estimated } \\
\text { study completion } \\
\text { date and References }\end{array}$ \\
\hline 1. & $\begin{array}{l}\text { Ivermectin Adjuvant to } \\
\text { Hydroxychloroquine and } \\
\text { Azithromycine in COVID19 } \\
\text { Patients (ClinicalTrials.gov } \\
\text { Identifier: NCT04343092) }\end{array}$ & $\begin{array}{l}\text { Drug: Ivermectin } \\
\text { Drug: Hydroxychloroquine } \\
\text { Sulfate } \\
\text { Drug: Placebos } \\
\text { Drug: Azithromycin } 500 \mathrm{mg}\end{array}$ & Phase 1 & $\begin{array}{l}50 \\
\text { participants }\end{array}$ & April 18, 2020 & August 1, 2020 [39] \\
\hline 2. & $\begin{array}{l}\text { Max Ivermectin- COVID } 19 \\
\text { Study versus Standard of Care } \\
\text { Treatment for COVID-19 Cases. } \\
\text { A Pilot Study (ClinicalTrials.gov } \\
\text { Identifier: NCT04373824) }\end{array}$ & Drug: Ivermectin & $\begin{array}{l}\text { Not } \\
\text { Applicable }\end{array}$ & $\begin{array}{l}50 \\
\text { participants }\end{array}$ & April 25, 2020 & July 25, $2020[40]$ \\
\hline 3. & $\begin{array}{l}\text { Ivermectin and Nitazoxanide } \\
\text { Combination Therapy for } \\
\text { COVID-19 (ClinicalTrials.gov } \\
\text { Identifier: NCT04360356) }\end{array}$ & $\begin{array}{l}\text { Combination Product: } \\
\text { Ivermectin plus Nitazoxanide } \\
\text { Other: Standard Care }\end{array}$ & $\begin{array}{l}\text { Phase } 2 \\
\text { Phase } 3\end{array}$ & $\begin{array}{l}100 \\
\text { participants }\end{array}$ & May 2020 & December 202 [41] \\
\hline 4. & $\begin{array}{l}\text { Ivermectin Effect on SARS- } \\
\text { CoV-2 Replication in Patients } \\
\text { with COVID-19(ClinicalTrials. } \\
\text { gov Identifier: NCT04381884) }\end{array}$ & $\begin{array}{l}\text { Drug: Ivermectin (IVER P®) } \\
\text { arm will receive IVM } 600 \mu \mathrm{g} / \\
\text { kg once daily plus standard } \\
\text { care. The control arm will } \\
\text { receive standard care. }\end{array}$ & Phase 2 & $\begin{array}{l}45 \\
\text { participants }\end{array}$ & May 7, 2020 & June $30,202[42]$ \\
\hline 5. & $\begin{array}{l}\text { Sars-CoV-2/COVID-19 } \\
\text { Ivermectin Navarra-ISGlobal } \\
\text { Trial (SAINT) (ClinicalTrials. } \\
\text { gov Identifier: NCT04390022) }\end{array}$ & $\begin{array}{l}\text { Drug: Ivermectin } \\
\text { Drug: Placebo }\end{array}$ & Phase 2 & $\begin{array}{l}24 \\
\text { participants }\end{array}$ & May 14,2020 & August 30, 2020 [43] \\
\hline 6. & $\begin{array}{l}\text { Trial to Promote Recovery from } \\
\text { COVID-19 With Ivermectin or } \\
\text { Endocrine Therapy (RECOVER) } \\
\text { (ClinicalTrials.gov Identifier: } \\
\text { NCT04374279) }\end{array}$ & $\begin{array}{l}\text { Drug: } \\
\text { Bicalutamide } 150 \mathrm{Mg} \text { Oral } \\
\text { Tablet } \\
\text { Drug: Ivermectin } 3 \mathrm{Mg} \text { Tab }\end{array}$ & Phase 2 & $\begin{array}{l}60 \\
\text { participants }\end{array}$ & June 2020 & June 2021 [44] \\
\hline 7. & $\begin{array}{l}\text { The Efficacy of Ivermectin } \\
\text { and Nitazoxanide in COVID-19 } \\
\text { Treatment (ClinicalTrials.gov } \\
\text { Identifier: NCT04351347) }\end{array}$ & $\begin{array}{l}\text { Drug: Chloroquine } \\
\text { Drug: Nitazoxanide } \\
\text { Drug: Ivermectin }\end{array}$ & $\begin{array}{l}\text { Phase } 2 \\
\text { Phase } 3\end{array}$ & $\begin{array}{l}60 \\
\text { participants }\end{array}$ & April 17, 2020 & $\begin{array}{l}\text { December 1, } 2030 \\
{[45]}\end{array}$ \\
\hline
\end{tabular}


Table 3: An approved regimen of IVM for treating COVID-19 as per the health department of the Republic of Peru [46]

\begin{tabular}{llll}
\hline Medicine & Dose & Duration & Route \\
\hline $\begin{array}{l}\text { Ivermectin } \\
\text { (solution oral } 6 \mathrm{mg} / \mathrm{ml})\end{array}$ & $200 \mathrm{mcg} / \mathrm{kg}$ & Single dose & Oral \\
\hline
\end{tabular}

Research Institute in Spain-Clínica Universidad de Navarra and the Barcelona Institute for Global Health (ISGlobal), have launched a clinical trial to investigate the effectiveness of IVM against COVID-19.

\section{APPROVAL OF IVM FOR TREATING COVID-19}

On May 8, 2020, the Health Department of the Republic of Peru approved IVM for the treatment of COVID-19 in humans [Table 3] [46]

\section{CONCLUSION}

With the exception of rare serious reactions, IVM is generally well tolerated. It has the clear advantages of ease of administration and better tolerability compared with the other possible options for COVID-19. As a nuclear import inhibitor, it has been shown promising antiviral activities for many viral infections. However, there is a lack of data establishing its antiviral activity in vivo. The recent studies of IVM efficacy on novel SARS-CoV2 have been performed in in vitro and in vivo settings each. Therefore, additional studies are required to establish its safety and efficacy for COVID-19. With results from an in vitro study revealing $99.8 \%$ reduction in viral RNA at $48 \mathrm{~h}$ and satisfactory results in critically ill patient's, the wonder drug IVM could be tried as a possible option for COVID-19 treatment in in vivo settings with animals, smaller number of human population shifting to larger clinical trials as soon as its efficacy gets established. We, therefore, hope that this wonder drug with in vivo studies could meet the unmet medical needs in the outbreak of COVID-19.

\section{FUNDING}

This work is not supported by any institution or organization.

\section{ACKNOWLEDGMENT}

The authors would like to thank Ramanachary namoju, Dr. A.V Kishore Babu, Dr. A. Srinivasa Rao, and other faculty members at Bhaskar Pharmacy College, Hyderabad, for their help in reviewing the manuscript.

\section{AUTHORS' CONTRIBUTIONS}

Talha Jabeen and Mohd Abdul Khader conceptualized all the research data and contributed to the preparation of this review and editing of the manuscript. Shayestha Jabeen contributed for literature search and manuscript editing.

\section{POTENTIAL CONFLICT OF INTERESTS}

All authors declare that they have no conflicts of interest.

\section{REFERENCES}

1. Lu H, Stratton CW, Tang Y. Outbreak of pneumonia of unknown etiology in Wuhan, China: The mystery and the miracle. J Med Virol 2020;92:401-2.

2. Singhal T. A review of coronavirus disease-2019 (COVID-19). Indian J Pediatr 2020;87:281-6.

3. Ayoub MD. Carvedilol as a potential addition to the covid-19 therapeutic arsenal. Int J Pharm Pharm Sci 2020;12:87-9.

4. Zhou Y, Hou Y, Shen J, Huang Y. Network-based drug repurposing for novel coronavirus 2019 nCoV/SARS-CoV-2. Cell Discov 2020;6:14.

5. Hudu SA, Shinkafi SH, Umar S. An overview of recombinant vaccine technology, adjuvants and vaccine delivery methods. Int J Pharm Pharm Sci 2016;8:19-4

6. Tayade MR, Shinkar DM, Patil PB, Saudagar RB. Emerging therapy for dengue. Int J Curr Pharm Sci 2018;10:1-4.
7. Yanuar A, Syahdi RR, Aryati WD. Parameter optimization and virtual screening Indonesian herbal database as human immunodeficiency virus-1 integrase inhibitor using autodock and vina. Int J App Pharm 2017;90:90-3

8. Caly L, Druce JD, Catton MG, Jans DA, Wagstaff KM. The FDAapproved drug ivermectin inhibits the replication of SARS-CoV-2 in vitro. Antivir Res 2020;178:104787.

9. Patel AN, David WG, Mandeep RM. Ivermectin in COVID-19 related critical illness. SSRN Electron J 2020; Available from: https://www. ssrn.com/abstract $=3570270$.

10. Ahmed SF, Quadeer AA, McKay MR. Preliminary identification of potential vaccine targets for the COVID-19 coronavirus (SARS-CoV-2) based on SARS-CoV immunological studies. Viruses 2020;12:254.

11. Morse JS, Lalonde T, Xu S, Liu WR. Learning from the past: Possible urgent prevention and treatment options for severe acute respiratory infections caused by 2019-nCoV. ChemBioChem 2020;21:730-8.

12. Prasad S, Cherian S, Abraham P. Transmission electron microscopy imaging of SARS-CoV-2. Indian J Med Res 2020;151:241-3.

13. Hoffmann M, Kleine-Weber H, Schroeder S, Krüger N, Herrler T, Erichsen $\mathrm{S}$, et al. SARS-CoV-2 cell entry depends on ACE2 and TMPRSS2 and is blocked by a clinically proven protease inhibitor. Cell 2020;181:271-80.

14. Ashour DS. Ivermectin: From theory to clinical application. Int J Antimicrob Agents 2019;54:134-42.

15. Laing R, Gillan V, Devaney E. Ivermectin-old drug, new tricks? Trends Parasitol 2017;33:463-72.

16. Frieman M, Yount B, Heise M, Kopecky-Bromberg SA, Palese P, Baric RS. Severe acute respiratory syndrome coronavirus ORF6 antagonizes STAT1 function by sequestering nuclear import factors on the rough endoplasmic reticulum/golgi membrane. J Virol 2007;81:9812-24

17. DailyMed-STROMECTOL-ivermectin tablet. Available from: http:// dailymed.nlm.nih.gov.

18. Tay MY, Fraser JE, Chan WK, Moreland NJ, Rathore AP, Wang C, et al. Nuclear localization of dengue virus (DENV) 1-4 non-structural protein 5; protection against all 4 DENV serotypes by the inhibitor ivermectin. Antivir Res 2013;99:301-6.

19. Lv C, Liu W, Wang B, Dang R, Qiu L, Ren J. Ivermectin inhibits DNA polymerase UL42 of pseudorabies virus entrance into the nucleus and proliferation of the virus in vitro and vivo. Antivir Res 2018;159:55-62.

20. Lee YJ, Lee C. Ivermectin inhibits porcine reproductive and respiratory syndrome virus in cultured porcine alveolar macrophages. Arch Virol 2016;161:257-68.

21. Varghese FS, Kaukinen P, Gläsker S, Bespalov M, Hanski L, Wennerberg K, et al. Discovery of berberine, abamectin and ivermectin as antivirals against chikungunya and other alphaviruses. Antivir Res 2016;126:117-24

22. Wagstaff KM, Sivakumaran H, Heaton SM, Harrich D, Jans DA. Ivermectin is a specific inhibitor of importin $\alpha / \beta$-mediated nuclear import able to inhibit replication of HIV-1 and dengue virus. Biochem J 2012;443:851-6.

23. Azeem S, Ashraf M, Rasheed MA, Anjum AA, Hameed R. Evaluation of cytotoxicity and antiviral activity of ivermectin against Newcastle disease virus. Pak J Pharm Sci 2015;28:597-602.

24. Yang SN, Atkinson SC, Wang C, Lee A, Bogoyevitch MA, Borg NA, et al. The broad spectrum antiviral ivermectin targets the host nuclear transport importin $\alpha / \beta 1$ heterodimer. Antivir Res 2020;177:104760.

25. Raza S, Shahin F, Zhai W, Li H, Alvisi G, Yang K, et al. Ivermectin inhibits bovine herpesvirus 1 DNA polymerase nuclear import and interferes with viral replication. Microorganisms 2020;8:409.

26. Lundberg L, Pinkham C, Baer A, Amaya M, Narayanan A, Wagstaff KM. Nuclear import and export inhibitors alter capsid protein distribution in mammalian cells and reduce venezuelan equine encephalitis virus replication. Antivir Res 2013;100:662-72.

27. Mastrangelo E, Pezzullo M, Burghgraeve TD, Kaptein S. Ivermectin is a potent inhibitor of flavivirus replication specifically targeting NS3 helicase activity: New prospects for an old drug. J Antimicrob 2012;67:1884-94

28. Gotz V, Magar L, Dornfeld D, Giese S. Influenza a viruses escape from MxA restriction at the expense of efficient nuclear vRNP import. Nature 2016;6:23138.

29. Rowland RR, Chauhan V, Fang Y, Pekosz A, Kerrigan M, Burton MD. Intracellular localization of the severe acute respiratory syndrome coronavirus nucleocapsid protein: Absence of nucleolar accumulation during infection and after expression as a recombinant protein in vero cells. J Virol 2005;79:11507-12.

30. Remme J, Baker RH, Sole GD, Dadzie KY. A community trial of ivermectin in the onchocerciasis focus of Asubende, Ghana. I. Effect on the microfilarial reservoir and the transmission of Onchocerca volvulus. Trop Med Parasitol 1989;40:367-74 
31. Sole GD, Remme J, Awadzi K, Accorsi S, Alley ES, Ba O, et al. Adverse reactions after large-scale treatment of onchocerciasis with ivermectin: Combined results from eight community trials. Bull WHO 1989;67:707-20.

32. Pacqué M, Muñoz B, Poetscke G, Foose J, Taylor HR, Greene BM. Pregnancy outcome after inadvertent ivermectin treatment during community-based distribution. Lancet 1990;336:1486-9.

33. Canga AZ, Prietp AM. The pharmacokinetics and interactions of ivermectin in humans-a mini-review. AAPS J 2008;10:42-6.

34. Grein J, Ohmagari N, Shin D, Diaz G, Asperges E, Castagna A. Compassionate use of remdesivir for patients with severe covid-19. N Engl J Med 2020;382:2327-36.

35. Cortegiani A, Ingoglia G, Ippolito M, Giarratano A, Einav S. A systematic review on the efficacy and safety of chloroquine for the treatment of COVID-19. J Crit Care 2020;57:279-83.

36. Human Prescription Drug Label. KALETRA-lopinavir and Ritonavir Tablet, Film Coated Kaletra-lopinavir and Ritonavir Solution. United States: AbbVie Inc. [Last accessed on 2019 Dec 26].

37. Abdolvahab MH, Mofrad MR, Schellekens H. Interferon beta: From molecular level to therapeutic effects. Int Rev Cell Mol Biol 2016;326:343-72.

38. Schmith VD. The approved dose of ivermectin alone is not the ideal dose for the treatment of COVID-19. Clin Pharmacol Ther 2020;2020:1889.

39. Gorial F. Efficacy of Ivermectin as Add on Therapy in COVID19 Patients: A Pilot Randomized Study. Report No: NCT04343092. Avaialable from: http://www.clinicaltrials.gov. [Last accessed on 2020 Jun 10].

40. Max Healthcare Insititute Limited. To Study the Effectiveness of Ivermectin With Standard of Care Treatment Versus Standard of Care Treatment for COVID 19 Cases. A Pilot Study. Report No: NCT04373824. Available from: http://www.clinicaltrials.gov. [Last accessed on 2020 May 10]

41. Okasha PD. Clinical Trial Evaluating Safety and Efficacy of Ivermectin and Nitazoxanide Combination as Adjuvant Therapy in COVID-19 Newly Diagnosed Egyptian Patients: A Tanta University Hope. Report No: NCT04360356. Available from: http://www.clinicaltrials.gov. [Last accessed on 2020 Apr 28].

42. Ivermectin Effect on SARS-CoV-2 Replication in Patients. Available from: http://www.COVID-19-fullTextView-ClinicalTrials.gov.

43. Sars-CoV-2/COVID-19 Ivermectin Navarra-ISGlobal. Available from: http://www.Trial-FullTextView-ClinicalTrials.gov.

44. Sidney Kimmel Comprehensive Cancer Center at Johns Hopkins. A Phase II Trial to Promote Recovery From COVID-19 With Ivermectin or Endocrine Therapy. Report No: NCT04374279. Available from: $\mathrm{http}: / /$ www.clinicaltrials.gov. [Last accessed on 2020 May 10].

45. Abd-Elsalam S. Clinical Study Evaluating the Efficacy of Ivermectin and Nitazoxanide in COVID-19 Treatment. Report No: NCT04351347. Available from: http://www.clinicaltrials.gov. [Last accessed on 2020 Apr 28].

46. How a Grass Roots Health Movement Led to Acceptance of Ivermectin as a COVID-19 Therapy in Peru. Available from: http://www. trialsitenews.com. 